\title{
Regional Distribution of Soil Phosphorus across Congregation-Grazing Zones of Forage-Based Pastures with Cow-Calf Operations in Florida
}

\author{
Gilbert C. Sigua ${ }^{1}$, Robert O. Myer ${ }^{2}$, Samuel W. Coleman ${ }^{1}$, Cheryl Mackowiak ${ }^{2}$, Martin Adjei ${ }^{3}$, \\ Chad C. Chase ${ }^{1}$, Joseph Albano ${ }^{4}$ \\ ${ }^{1}$ United States Department of Agriculture-Agricultural Research Service, Brooksville, USA; ${ }^{2}$ North Florida Research and Educational
Center, University of Florida, Marianna, USA; ${ }^{3}$ University of Florida, Range Cattle Research and Education Center, Ona, USA; ${ }^{4}$ United
States Department of Agriculture-Agricultural Research Service, Fort Pierce, USA.
Email: gilbert.sigua@ars.usda.gov
}

Received October 19 $9^{\text {th }}, 2010$; revised February 19 $9^{\text {th }}, 2011$; accepted March $22^{\text {nd }}, 2011$.

\begin{abstract}
The arrangement of supplemental feed, water, shelter, and their concurrent interactions with topographic features may influence the distribution of animals and their simultaneous use of pasture's resources. The effects of grazing and/or congregation management that control phosphorus cycling and distribution have not been sufficiently evaluated. The objectives of this study were: 1) to determine whether cattle congregation sites typical on most Florida ranches, represented by water troughs and shaded areas, are more phosphorus-rich and may contribute more soluble phosphorus to surface water run-off and groundwater than other pasture locations; and 2) to assess the regional distribution of Mehlich-1 extractable soil phosphorus (MP) across congregation-grazing zones of forage-based pastures with cow-calf operations in Florida. Soil samples were collected at increasing distance from congregations structures (water troughs and shades) in established (>10 yr), grazed beef cattle pastures located in three Florida regions. Samples were collected in the fall and spring of 2005, 2006, and 2007, respectively; following a radial (every 90 degrees) sampling patterns away from the center of the congregation structures. Averaged across years, MP and soil phosphorus saturation in the congregation zones were comparable $(p \leq 0.05)$ with MP values and soil phosphorus saturation in the grazing zones at all three Florida regions. Average MP at all three pasture locations did not exceed the crop requirement

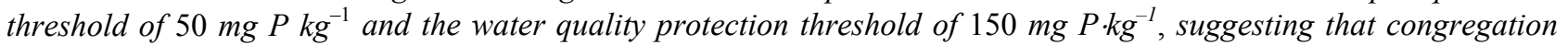
zones in beef cattle pastures at all three regions of Florida are not phosphorus-rich.
\end{abstract}

Keywords: Beef Cattle, Congregation Structures, Congregation Zone, Grazing Zone, Total Phosphorus, Phosphorus Saturation, Nutrient Management

\section{Introduction}

Livestock concentration areas in pastures can be important point sources of nutrient pollution and are often perceived to have higher amounts of soil phosphorus and nitrogen compared with less disturbed areas of the pasture. The arrangement of supplemental feed, water, shelter, and their concurrent interactions with topographic features obviously influences the distribution of animals and their use of pasture's resources [1]. Distribution and movement patterns of cattle are particularly valuable in allocating and assessing utilization impacts on a given pasture. Movement of free-ranging cattle varies due to spatial arrangement of forage resources within pastures
[2] and the proximity of water [3,4], mineral feeders [5], and shades to grazing sites. Temperate British breeds (Angus and Hereford) of Bos taurus cows grazed less during the day in warm environments than tropically adapted Senepol cows, but compensated for reduced grazing activity during the hotter parts of the day by increasing time spent grazing at night $[6,7]$. Grazing animals congregate close to the shade and watering areas during the warmer periods of the day especially during summer months $[8,9]$.

Grazing animals have dominant effects on the movement and utilization of nutrients through the plant-soil system, and thus on the fertility of pasture soils [10-12]. 
Grazing can accelerate and alter the timing of nutrient transfers, and increase the amount of nutrients cycled from soil to plant [13]. The position of shade and water sources could influence the spatial distribution of soil biochemical properties including soil organic carbon and nitrogen, particulate organic carbon, nitrogen, microbial biomass, and net nitrogen mineralization [14].

The rate at which soil phosphorus accumulates in terrestrial beef cattle agro-ecosystem is uncertain, as are the mechanisms responsible for the current phosphorus sink and/or source. Broad knowledge of cattle movement in pastures is critical to understanding their impact on agro-ecosystems. We hypothesized that cattle congregation sites are more nutrient-rich and may contribute more nutrients to surface and groundwater supply and may have higher concentrations of soil phosphorus than in other pasture locations. There was a correlation between time spent in a particular area especially close to shade and water, and the number of excretions and this behavior could lead to an increase in the concentrations of soil nutrients [15]. Congregation areas may receive a significantly greater daily fecal and urinary load compared with less affected areas of the pasture [15-17].

Phosphorus management in soils is of concern to water quality protection, as losses of phosphorus in surface runoff can accelerate the eutrophication of surface wasters [18-22]. Agricultural soils considered high in phosphorus can cause significant movement of phosphorus into waterways in dissolved and particulate forms $[23,24]$. Forage-beef cattle operations must adopt an integrated approach that will lead to the development of appropriate sustainable pasture technologies that optimize beef cattle ranching profitability. Thus, both actual and perceived environmental problems associated with beef cattle production systems need to be addressed when new management systems are being developed.

Although several studies have documented livestock concentration effects on soil properties under controlled conditions $[14,25,26]$, the effects of animal congregation management that control phosphorus cycling and distribution have not been sufficiently evaluated and reported. Lack of a clear relationship between grazing practices and phosphorus dynamics may be attributed to inherent soil variations, depth of soil sampling, and insufficient evaluation of phosphorus distributions within pasture system $[27,28]$. The objectives of this study were: 1 ) to evaluate whether cattle congregation sites such as water troughs and shade areas, typical on most Florida ranches, are more phosphorus-rich and therefore contribute more soluble phosphorus to surface and groundwater supply than in other pasture locations; and 2) to assess the regional distribution of soil phosphorus across congrega- tion-grazing zones of forage-based pastures with cowcalf operations in Florida.

\section{Materials and Methods}

\subsection{Study Sites Location and Description}

The study sites were located in three (Brooksville, Ona and Marianna) Florida pastures with cow-calf operations. The site in Brooksville, FL (central region) was at Turnley Unit $\left(82.29^{\circ} \mathrm{W} ; 28.62^{\circ} \mathrm{N}\right)$ of the USDA-ARS, Subtropical Agricultural Research Station [12]. Soil (Candler fine sand) at this location can be described as well-drained hyperthermic uncoated typic quartzipsamments [29]. The study site in Ona, Florida (southern region) was located at the University of Florida Range Cattle Research and Education Center $\left(82.92^{\circ} \mathrm{W} ; 27.43^{\circ} \mathrm{N}\right)$ on a Pomona fine sandy soil (Sandy, siliceous, hyperthermic ultic alaquods). The study site in Marianna, FL (northern region) was located at the University of Florida North Florida Research and Education Center $\left(85.18^{\circ} \mathrm{W}\right.$; $30.87^{\circ} \mathrm{N}$ ) on a well drained acidic, sandy soil (fine loamy, kaolinitic, thermic kandiudults). Figure 1 shows the locations of the different study sites.

Cattle production at these three pasture locations is forage-based with perennial tropical grass, bahiagrass (Paspalum notatum, Flugge), the predominant species. The other major forage species in Brooksville, Marianna and Ona are rhizoma peanuts (Arachis glabrata, Benth), bermudagrass (Cynodon dactylon, L.) and limpograss (Hemarthria altissima), respectively. All the pasture fields that were included in this study received annual nitrogen fertilization of $90 \mathrm{~kg} \mathrm{~N} \cdot \mathrm{ha}^{-1}$ that was based on the University of Florida's recommendation [30].

Table 1 shows some of the selected properties of surface $(0-20 \mathrm{~cm})$ soils at the study sites. The three-year (2005-2007) average of rainfall distribution in the study sites were $121 \mathrm{~cm}, 122 \mathrm{~cm}$ and $122 \mathrm{~cm}$ for Brooksville, Ona and Marianna, respectively with approximately half of these rainfall amounts occurring during mid-June through mid-September (Figure 2).

\subsection{Soil Sampling, Sample Preparation and Soil Analyses}

Soil samples around the congregations structures (water troughs and shades) in established ( $>10 \mathrm{yr}$ ), grazed beef cattle pastures at each location (Brooksville, $\mathrm{n}=280$; Ona, $\mathrm{n}=260$; and Marianna, $\mathrm{n}=280$ ) were collected in the fall and spring of 2005, 2006, and 2007, respectively. Soil samples were collected at $0-15 \mathrm{~cm}$ and $15-30 \mathrm{~cm}$ from different locations around the congregation structures following a radial (every 90 degrees) sampling pattern at $0.9,1.7,3.3,6.7,13.3,26.7$, and $53.3 \mathrm{~m}$ from the 


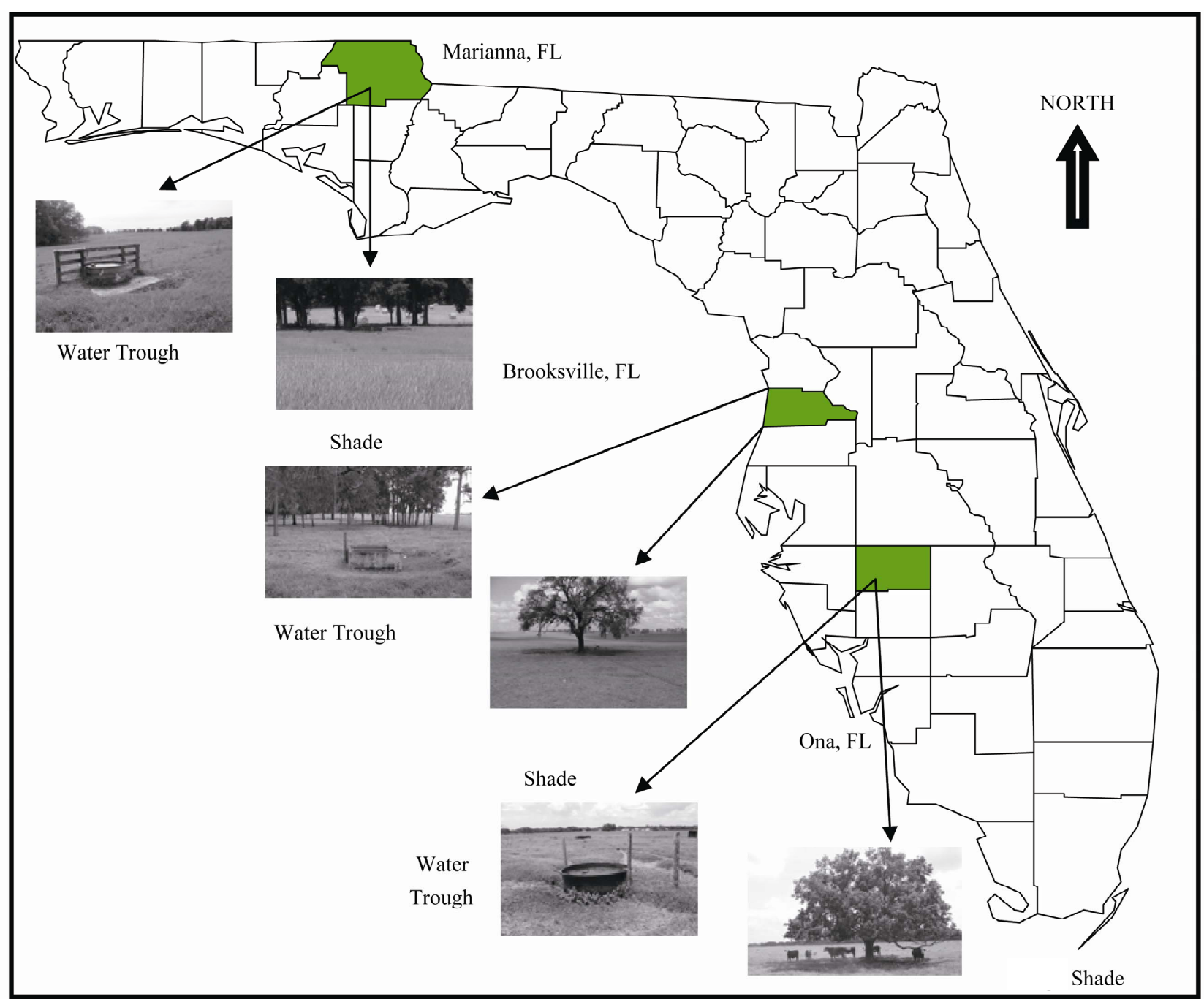

Figure 1. Location of study sites in Florida (Brooksville, Ona and Marianna).

Table 1. Average properties of surface soil $(0-20 \mathrm{~cm})$ across the congregation-pasture interface of three Florida pastures (Brooksville, Marianna, and Ona).

\begin{tabular}{|c|c|c|c|}
\hline Soil Properties & Brooksville, FL & Marianna, FL & Ona, FL \\
\hline \multicolumn{4}{|l|}{ Particle Size } \\
\hline Sand $\left(\mathrm{g} \cdot \mathrm{kg}^{-1}\right)$ & $825 \pm 38$ & $944 \pm 24$ & $962 \pm 24$ \\
\hline Silt $\left(g \cdot \mathrm{kg}^{-1}\right)$ & $125 \pm 38$ & $44 \pm 14$ & $12 \pm 2$ \\
\hline Clay $\left(g \cdot \mathrm{kg}^{-1}\right)$ & $50 \pm 6$ & $12 \pm 0.2$ & $25 \pm 4$ \\
\hline $\mathrm{pH}\left(\right.$ in $\left.\mathrm{H}_{2} \mathrm{O}\right)$ & $6.4 \pm 0.1$ & $5.9 \pm 0.8$ & $5.7 \pm 0.8$ \\
\hline Calcium $\left(\mathrm{mg} \cdot \mathrm{kg}^{-1}\right)$ & $603 \pm 171$ & $273 \pm 37$ & $593 \pm 65$ \\
\hline Magnesium (mg. $\left.\mathrm{kg}^{-1}\right)$ & $89 \pm 4.6$ & $35 \pm 6$ & $134 \pm 24$ \\
\hline Potassium $\left(\mathrm{mg} \cdot \mathrm{kg}^{-1}\right)$ & $48 \pm 11$ & $70 \pm 11$ & $135 \pm 44$ \\
\hline Soil Organic Carbon $\left(\mathrm{g} \cdot \mathrm{kg}^{-1}\right)$ & $4 \pm 0.4$ & $3 \pm 1.7$ & $6 \pm 2.0$ \\
\hline
\end{tabular}




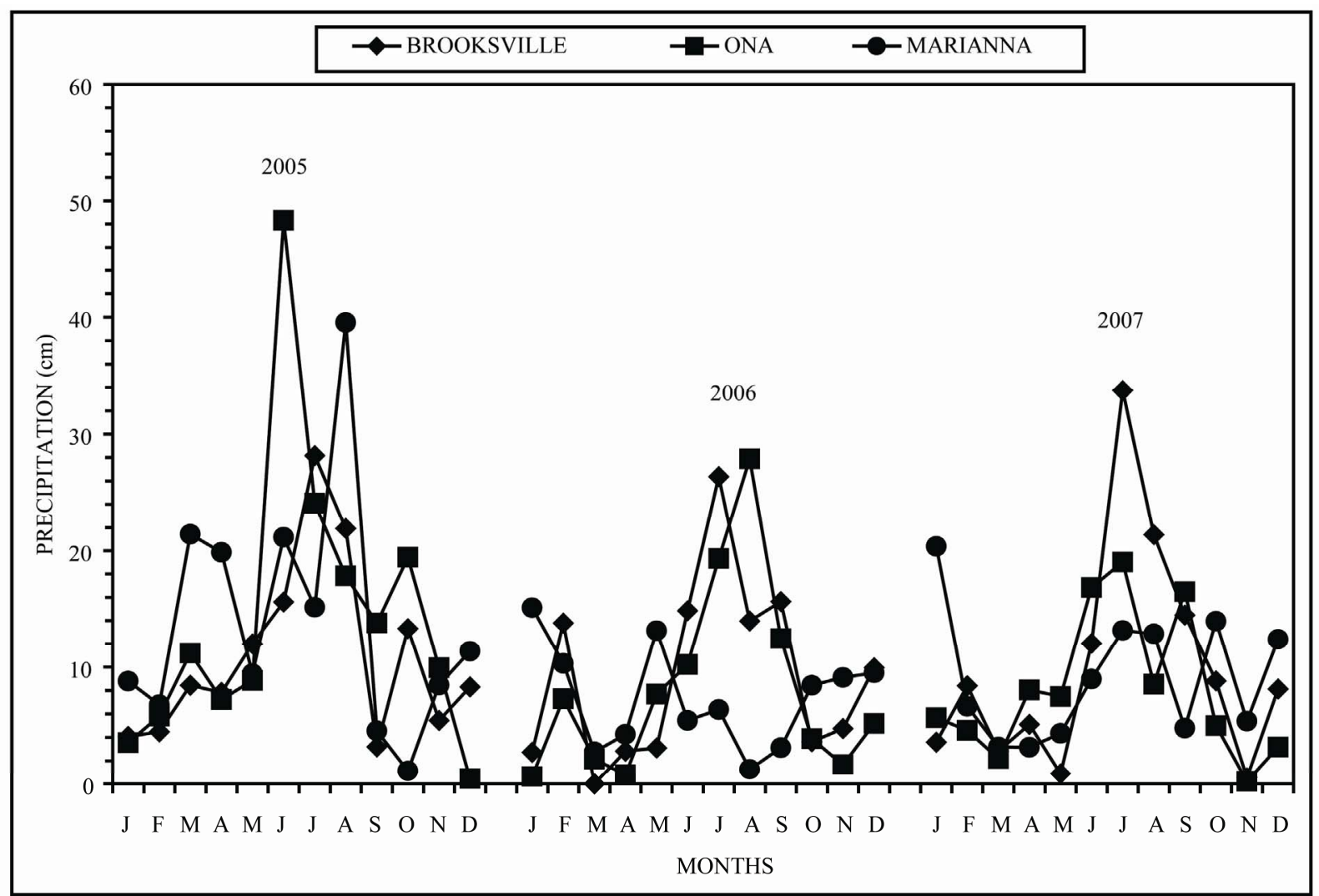

Figure 2. Monthly rainfall distribution in the study area (Brooksville, FL; Ona, Florida; Marianna, FL).

approximate center of water troughs and shaded areas (Figure 3). For the purpose of this study, sampling sites at $0.9,1.7$, and 3.3 from the center of the congregation structures were referred to as the "congregation zone" while sites located at 13.3, 26.7 and $53.3 \mathrm{~m}$ away from the center of the congregation structures were referred to as the "grazing zone".

Soil samples were air-dried and passed through a 2-mm mesh sieve prior to chemical extraction of soil phosphorus. Sample extractions were conducted at USDA-ARS Laboratory located in Brooksville, FL. Soil available phosphorus was extracted with double acid $\left(0.025 \mathrm{~N} \mathrm{H}_{2} \mathrm{SO}_{4}+0.05 \mathrm{~N} \mathrm{HCl}\right)$ [31] and analyzed using an inductively coupled spectrophotometer at USDA Horticultural Laboratory located in Fort Pierce, FL. The degree of soil saturation with phosphorus (DPS) as described in Equation (1) was computed using the phosphorus, iron, and aluminum contents $\left(\mathrm{mg} \cdot \mathrm{kg}^{-1}\right)$ of the soils.

$$
\operatorname{DPS}(\%)=([\mathrm{P}] \times 100) /[\mathrm{Fe}+\mathrm{Al}]
$$

\subsection{Statistical Analysis}

Data were analyzed with a three-way ANOVA using PROC GLM [32]. The model included year (Y), pasture location (PL), and pasture zone (PZ). The pooled data (2005-2007) were tested initially for normality [32]. For this study, F-test indicated highly significant $(\mathrm{p} \leq 0.0001)$ year and pasture location effects, so means of PZ effects on soil phosphorus and DPS were separated following the procedures of Duncan Multiple Range Test [32] by year. PROC REG method [32] was used to evaluate the relationship of soil phosphorus concentration with distance away from the center of congregation structures.

\section{Results and Discussion}

\subsection{Mehlich-1 Extractable Soil Phosphorus}

Soil phosphorus concentration varied among the pasture locations $(\mathrm{p} \leq 0.0001)$ and pasture zone $(\mathrm{p} \leq 0.001)$. There was an interaction between pasture location and pasture zone $(\mathrm{p} \leq 0.001)$ and interaction effects among year, pasture location, and pasture zone $(\mathrm{p} \leq 0.0001)$. Soil phosphorus concentration also varied with radial distance away from the center of the congregation structures $(p \leq 0.001)$. Averaged across years and pasture zones, pasture located in Brooksville, FL ((46.6 \pm 5.3$\left.) \mathrm{mg} \cdot \mathrm{kg}^{-1}\right)$ had the greatest available soil phosphorus while pasture at Marianna, FL had the lowest concentrations of 


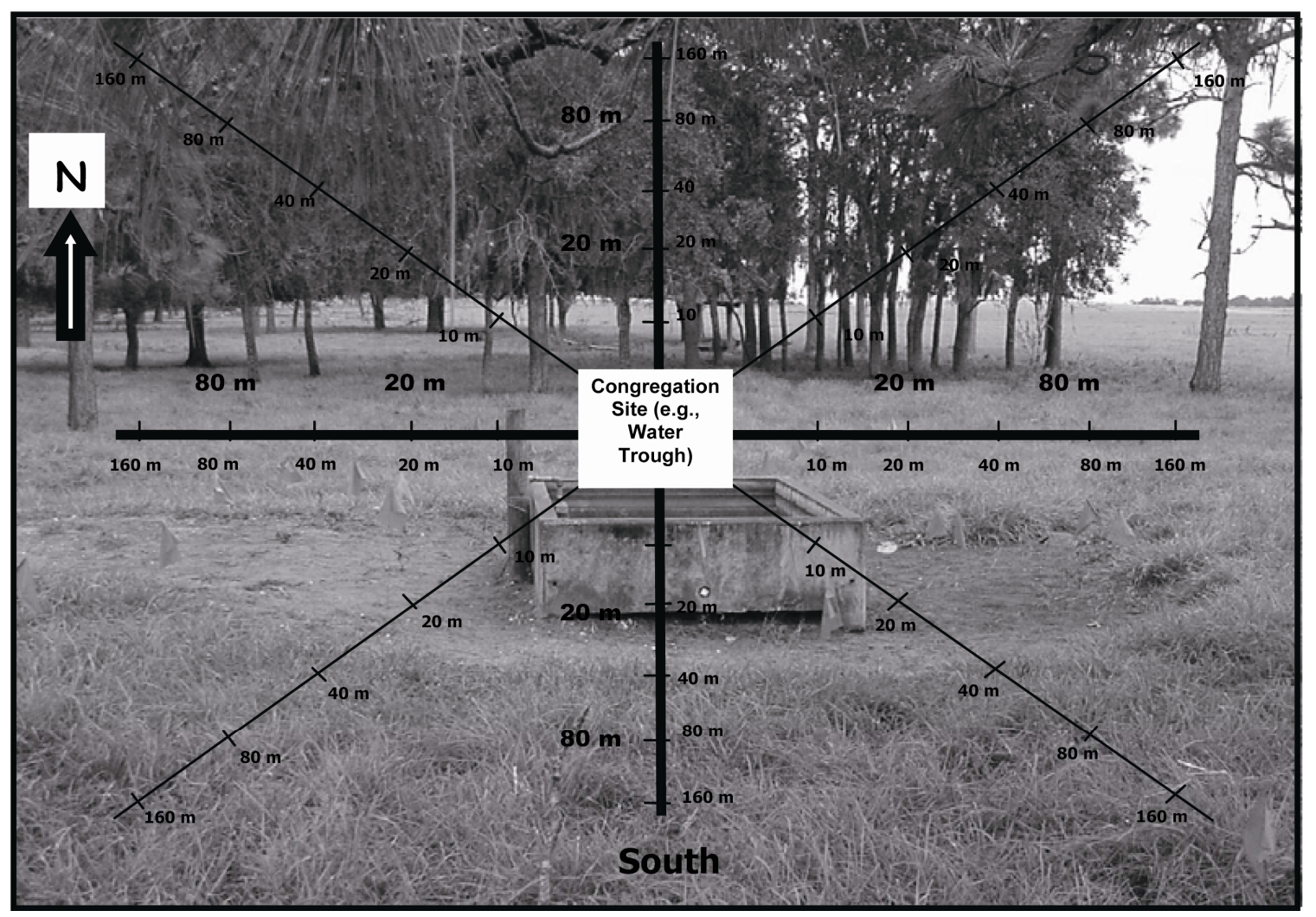

Figure 3. Sampling location and sampling scheme following radial (every 90 degrees: north, south, east and west direction) patterns at $0.9,1.7,3.3,13.3,26.7$ and 53.3 meters away from the approximate center of congregation structures (e.g. water troughs, shades/tree).

soil phosphorus $\left((26.7 \pm 1.4) \mathrm{mg} \cdot \mathrm{kg}^{-1}\right)$. The amount of soil phosphorus in pasture located in Ona, FL was about $(45.5 \pm 4.2) \mathrm{mg} \cdot \mathrm{kg}^{-1}$ (Table 2$)$. The average concentrations of soil phosphorus at all three regions were still not high enough to be of environmental concern. Average concentration of phosphorus at all three pasture locations did not exceed the crop requirement threshold of $50 \mathrm{mg} \mathrm{P} \cdot \mathrm{kg}^{-1}$ [33] nor exceeded the water quality protection threshold of $150 \mathrm{mg} \mathrm{P} \cdot \mathrm{kg}^{-1}$ [34]. Losses of soil phosphorus by overland flow can become a big concern when the concentrations for soil phosphorus exceeded $150 \mathrm{mg} \cdot \mathrm{kg}^{-1}$.

Spatial trends of soil phosphorus in our study may be a function of feces and urine deposition where animals clustered. Where animals congregate may tend to develop some hot spots in the pasture. Our results did not support the idea that hot spots were likely had the highest concentration of soil phosphorus. Soil phosphorus concentrations in the congregation zones were comparable ( $p$ $\leq 0.05$ ) with the concentrations of soil phosphorus in the grazing zones at all the three regions, except for Brooksville site (Table 2). The grazing zone of pastures located in Brooksville, FL had the highest concentrations of soil phosphorus $\left((51.6 \pm 5.1) \mathrm{mg} \cdot \mathrm{kg}^{-1}\right)$ while congregation zone of pastures in Marianna, FL had the lowest levels of soil phosphorus $\left((26 \pm 1.3) \mathrm{mg} \cdot \mathrm{kg}^{-1}\right)$.

The concentrations of soil phosphorus decreased linearly with distance away from center of the congregation structures at all three Florida regions. Figure 4 shows the relationships between extractable soil phosphorus and distance away for the center of the shaded areas in Brooksville, Ona and Marianna, FL. The regression models that described the relationship of Mehlich-1 extractable (MP) soil phosphorus with distance away from the center of shaded areas are given below.

$$
\begin{aligned}
& \mathrm{MP}_{\mathrm{BKV}}=-5.6 \mathrm{x}+65.7 ; R^{2}=0.78^{* *} \\
& \mathrm{MP}_{\mathrm{ONA}}=-4.4 \mathrm{x}+41.8 ; R^{2}=0.87 * * \\
& \mathrm{MP}_{\mathrm{MAR}}=-1.4 \mathrm{x}+43.6 ; R^{2}=0.46^{*}
\end{aligned}
$$

Regression models that describe the relationship of MP and distance away from the center of water troughs in Brooksville, Ona and Marianna, FL are shown in Figure 5. These regressions models are further described below (Equations 5-7).

$$
\begin{aligned}
& \mathrm{MP}_{\mathrm{BKV}}=-9.6 \mathrm{x}+80.4 ; R^{2}=0.74 * * \\
& \mathrm{MP}_{\mathrm{ONA}}=-6.5 \mathrm{x}+80.5 ; R^{2}=0.59 *
\end{aligned}
$$


Table 2. Comparative concentrations of Mehlich-1 extractable phosphorus, aluminum, iron and percent phosphorus saturation in soils $(0-20 \mathrm{~cm})$ among the different pasture zones of three Florida pastures (Brooksville, Ona and Marianna).

\begin{tabular}{|c|c|c|c|c|c|c|}
\hline $\begin{array}{c}\text { Pasture } \\
\text { Location }\end{array}$ & $\begin{array}{l}\text { Pasture } \\
\text { Zone }\end{array}$ & $\begin{array}{c}\text { Sample } \\
\text { Number (n) }\end{array}$ & $\begin{array}{c}\text { Phosphorus } \\
\left(\mathrm{mg}^{\left.-k^{-1}\right)}\right.\end{array}$ & $\begin{array}{l}\text { Aluminum } \\
\left(\mathrm{mg}^{\prime} \mathrm{kg}^{-1}\right)\end{array}$ & $\begin{array}{c}\text { Iron } \\
\left(\mathrm{mg}^{-1 g^{-1}}\right)\end{array}$ & $\begin{array}{c}\text { Soil Phosphorus } \\
\text { Saturation (\%) }\end{array}$ \\
\hline \multirow[t]{3}{*}{ 1. Brooksville, FL } & Congregation & 211 & $39.7 \pm 4.3 \mathrm{~b}^{\dagger}$ & $289.8 \pm 47.0 \mathrm{~b}$ & $8.9 \pm 2.1 \mathrm{a}$ & 13.2 \\
\hline & Grazing & 187 & $51.6 \pm 5.1 \mathrm{a}$ & $457.1 \pm 55.3 \mathrm{a}$ & $11.1 \pm 2.3 \mathrm{a}$ & 11.0 \\
\hline & Transition & 70 & $49.2 \pm 6.4 \mathrm{a}$ & $416.1 \pm 57.1 \mathrm{a}$ & $11.9 \pm 2.8 \mathrm{a}$ & 11.5 \\
\hline Mean & & & $46.6 \pm 5.3$ & $387.7 \pm 53.1$ & $10.6 \pm 2.4$ & 11.9 \\
\hline \multirow[t]{3}{*}{ 2. Ona, FL } & Congregation & 244 & $45.1 \pm 4.5 \mathrm{~b}$ & $71.8 \pm 4.5 \mathrm{a}$ & $11.9 \pm 1.1 \mathrm{a}$ & 53.8 \\
\hline & Grazing & 224 & $39.2 \pm 3.4 \mathrm{~b}$ & $68.1 \pm 4.1 \mathrm{a}$ & $13.6 \pm 1.2 \mathrm{a}$ & 47.9 \\
\hline & Transition & 82 & $52.2 \pm 4.7 \mathrm{a}$ & $62.2 \pm 3.3 \mathrm{a}$ & $12.1 \pm 0.9 \mathrm{a}$ & 70.2 \\
\hline Mean & & & $45.5 \pm 4.2$ & $67.4 \pm 3.9$ & $12.5 \pm 1.1$ & 57.3 \\
\hline \multirow[t]{3}{*}{ 3. Marianna, FL } & Congregation & 240 & $26.5 \pm 1.3 \mathrm{a}$ & $118.2 \pm 3.3 b$ & $2.2 \pm 0.09 \mathrm{a}$ & 22.1 \\
\hline & Grazing & 188 & $29.0 \pm 1.4 \mathrm{a}$ & $135.5 \pm 4.7 \mathrm{a}$ & $1.8 \pm 0.08 \mathrm{~b}$ & 21.1 \\
\hline & Transition & 78 & $24.7 \pm 1.5 \mathrm{a}$ & $144.9 \pm 5.0 \mathrm{a}$ & $2.2 \pm 0.09 \mathrm{a}$ & 16.8 \\
\hline Mean & & & $26.7 \pm 1.4$ & $132.9 \pm 4.3$ & $2.1 \pm 0.08$ & 20.0 \\
\hline Sources of Variations & & & F-Value & F-Value & F-Value & F-Value \\
\hline Year $(Y)$ & & & $140.9^{* * * *}$ & $244.7 * * *$ & $26.4 * * *$ & $103.7^{* * *}$ \\
\hline Pasture Location (PL) & & & $114.2 * * *$ & $298.1 * * *$ & $51.9^{* * *}$ & $38.2 * *$ \\
\hline Pasture Zone (PZ) & & & $61.7 * *$ & $1.9^{\mathrm{ns}}$ & $3.4^{*}$ & $7.4^{* *}$ \\
\hline $\mathrm{PL} \times \mathrm{PZ}$ & & & $110.9 * * *$ & $1.4^{\mathrm{ns}}$ & $3.6^{*}$ & $1.6^{\mathrm{ns}}$ \\
\hline $\mathrm{Y} \times \mathrm{PL} \times \mathrm{PZ}$ & & & $11.1^{* *}$ & $1.6^{\mathrm{ns}}$ & $3.9^{* *}$ & $0.4^{\mathrm{ns}}$ \\
\hline
\end{tabular}

${ }^{\dagger}$ Means in column within each subheading followed by common letter(s) are not significantly different from each other at $\mathrm{p} \leq 0.05 .{ }_{* * *-}^{*}(\mathrm{p} \leq 0.0001),{ }_{* *-}(\mathrm{p} \leq$ $0.001), *-(p \leq 0.01), n s-$ not significant.

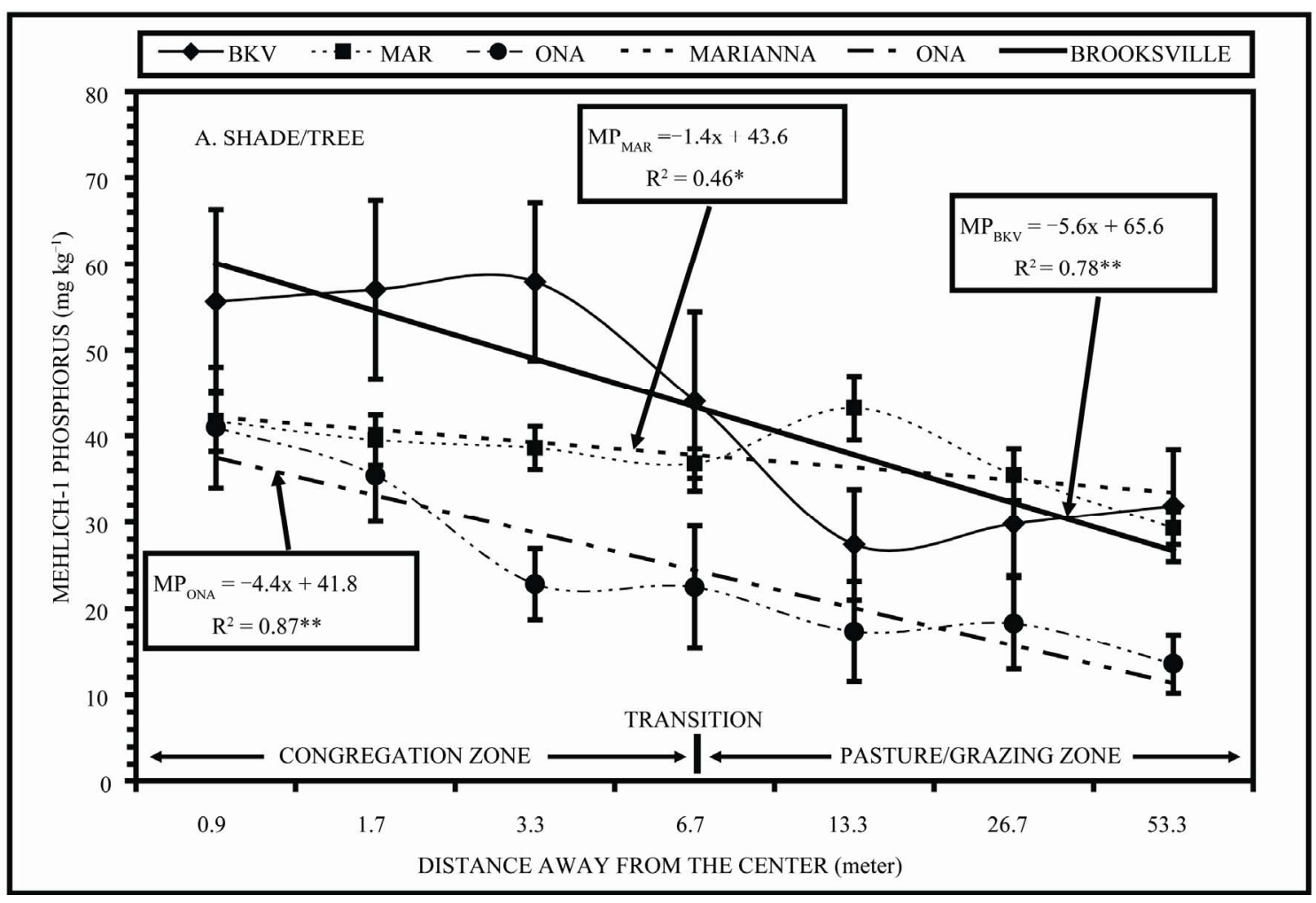

Figure 4. Concentration of Mehlich-1 extractable soil phosphorus (MP) at and/or away from the center of congregation structure (shade/tree). 


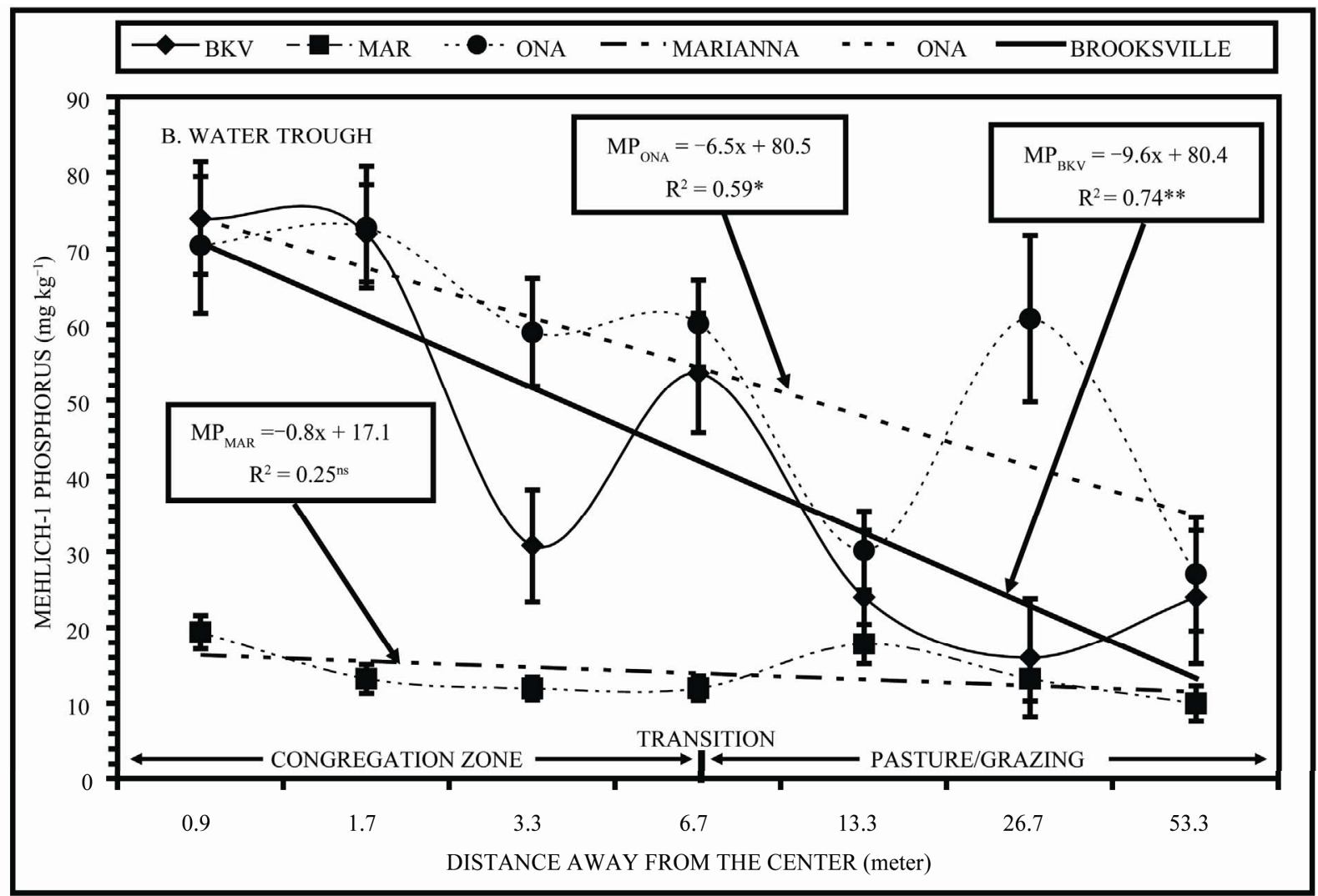

Figure 5. Concentration of Mehlich-1 extractable soil phosphorus (MP) at and/or away from the center of congregation structure (water trough).

$$
\mathrm{MP}_{\mathrm{MAR}}=-0.8 \mathrm{x}+17.1 ; R^{2}=0.25^{\mathrm{ns}}
$$

Results from our study did not support our hypothesis that cattle congregation sites in Florida ranches may have greater potential to sequester soil phosphorus. Early results of a study suggest that congregation zones may not be as nutrient-rich as previously thought, therefore may not contribute more nutrients to surface and groundwater [12]. The Mehlich-1 extractable soil phosphorus in our study area is less than $150 \mathrm{mg} \cdot \mathrm{kg}^{-1}$, the threshold above which a crop production and environmental caution. However, the congregation zones usually do not have vegetation, which makes soil phosphorus more susceptible to surface runoff during rainfall events.

Intensive cattle trampling in areas around cattle congregation sites, especially within the congregation zone ( 0.9 to 3.3 meters away) may help to explain our results. Trampling by cattle during certain periods of the year may substantially damage the main components of pasture and/or grassland systems (plants, soil structure and soil biology). The effects of trampling on plant productivity, root growth and physical soil properties have been studied [35]. Trampling within a congregation zone may lead to destruction of a large portion of aerial system, stolons and roots, followed by removal of vegetation cover resulting to at least $50 \%$ bare surface [35].

The effects of trampling, especially at or within the congregation zone may also lead to the destruction of soil aggregates, which could have some significant effects on soil phosphorus dynamics within the congregation zones [36]. Mixing or total destruction of soil aggregates within the congregation zone may result to mixing and spreading of phosphorus as a result of the separations among the different aggregate sizes. Total phosphorus increased with decreasing soil aggregate size [37]. The extent to which individual soil aggregates influence soil phosphorus concentrations will partly depend on the soil aggregate's phosphorus buffering capacity (PBC). The soil aggregate's PBC represents a means of quantifying the relative strength with which soil aggregate can influence surrounding solution and is derived by dividing the quantity (Q) of phosphorus that a given amount of soil aggregates can sorbed by the intensity (I) of phosphorus that the soil aggregates can maintain in solution [38]. Mixing or total destruction of soil aggregates could result in much lower Q and I when compared to the other parts of the pasture with less soil compaction. 


\subsection{Soil Phosphorus Saturation}

The degree of phosphorus saturation in soils was significantly $(\mathrm{p} \leq 0.0001)$ affected by year, pasture location and pasture zone (Table 2). Averaged across years and pasture zones, the pastures at Ona, FL had the highest estimated degree of soil phosphorus saturation at $57.3 \%$ followed by pastures located at Marianna, FL (20.0\%). Pastures at Brooksville, FL had the lowest estimated degree of soil phosphorus saturation (11.9\%).

The degree of soil phosphorus saturation in the congregation zones $(13.2 \%)$ of pastures located in Brooksville, FL was comparable to the levels of phosphorus saturation in the grazing zones $(11.0 \%)$. Similarly, the degree of soil phosphorus saturation did not vary between the congregation zones $(22.1 \%)$ and grazing zones $(21.1 \%)$ of pastures at Marianna, FL. The degree of soil phosphorus saturation in congregation zones and grazing zones of pastures located in Ona, FL were $53.6 \%$ and $47.9 \%$, respectively (Table 2). The varying amount of aluminum and iron among the different pasture locations and pasture zones may have had affected the spatial distribution of soil phosphorus saturations in the soils. The low concentrations of aluminum and iron within pasture zones of pastures located in Ona, FL may explained the highest degree of soil phosphorus saturation at this regional site when compared with the average levels of aluminum and iron in pastures located at Brooksville, FL and/or Marianna, FL. Averaged across pasture zones and years, the levels of aluminum $\left(\mathrm{mg} \cdot \mathrm{kg}^{-1}\right)$ in three regions are as follows: Brooksville $(387.7 \pm 53.1)>$ Marianna $(132.9 \pm 4.3)>$ Ona $(67.4 \pm 3.9)$. The levels of iron across pasture zones and were as follows: Ona (12.5 \pm $1.1)>$ Brooksville $(10.6 \pm 2.4)>$ Marianna $(2.1 \pm 0.1)$.

Results of multiple regression analyses on the levels of Mehlich-1 extractable soil phosphorus (MP) saturation with concentrations of aluminum and iron in the region were significant, but rather weak relationship with $R^{2}$ values ranged from 0.12 to 0.67 . The levels of MP saturation in three regions can be explained by the following relationships:

$$
\begin{aligned}
& \mathrm{MP}_{\mathrm{BKV}}=22.2-0.01[\mathrm{Al}]+1.8[\mathrm{Fe}] ; R^{2}=0.67 * * \\
& \mathrm{MP}_{\mathrm{ONA}}=43.9+0.22[\mathrm{Al}]-1.2[\mathrm{Fe}] ; R^{2}=0.12^{*} \\
& \mathrm{MP}_{\mathrm{MAR}}=22.8-0.05[\mathrm{Al}]+5.2[\mathrm{Fe}] ; R^{2}=0.14 *
\end{aligned}
$$

Our results (Equations 7 to 9 ) showed variable effects of iron and aluminum concentrations on the levels of soil phosphorus among the different pasture locations. Our observations are quite similar to the observations reported earlier [39]. Their studies support the absence of significant and positive correlations between phosphorus retention and iron and added phosphorus may have been preferred onto aluminum over iron. The preference of phosphorus for either aluminum or iron may have resulted because the soil iron may be more saturated in phosphorus than aluminum or because the soil aluminum was more saturated in phosphorus than iron.

The degree of soil phosphorus saturation has been suggested as an indicator for the risk of phosphorus loss from agricultural soils [40,41]. Overall, the degree of soil phosphorus saturation from pastures in our study did not exceed the environmental threshold of phosphorus saturation. Other studies $[41,42]$ have found that the degree of phosphorus saturation in soils needs to exceed $60 \%$ before dissolved reactive phosphorus becomes an environmental problem. Our results were below this saturation, suggesting that phosphorus buildup and/or release is unlikely anywhere in the pasture, including the congregation zones.

\section{Summary and Conclusions}

Results from this study suggest that congregation zones in pastures with beef cattle operations in three regions of Florida are not phosphorus-rich, therefore may not contribute more phosphorus to surface and groundwater supply under Florida conditions. Averaged across years, phosphorus concentrations and soil phosphorus saturation of the congregation zones were comparable $(\mathrm{p} \leq$ $0.05)$ with soil phosphorus and soil phosphorus saturation in the grazing zones of all the three regions. Average phosphorus in all three pasture locations did not exceed the crop requirement threshold of $50 \mathrm{mg} \mathrm{P} \cdot \mathrm{kg}^{-1}$ and the water quality protection threshold of $150 \mathrm{mg} \mathrm{P} \cdot \mathrm{kg}^{-1}$.

The degree of soil phosphorus saturation in the three pastures were below the environmental threshold of phosphorus saturation (DPS $\geq 60 \%$ ), suggesting that phosphorus buildup and/or release is not a predicament anywhere in the pasture, including the congregation zones. These results may have significant implications for the transport of phosphorus to surface waters and our ability to predict and model losses of phosphorus from congregation zone or grazing zone of pastures with cow-calf operations.

\section{REFERENCES}

[1] D. Ganskopp, "Slope Use By Cattle, Feral Horses, Deer And Bighorn Sheep," Northwest Science, Vol. 61, No. 2, 1987, pp. 74-81.

[2] R. L. Senft, L. R. Rittenhouse and R. G. Woodmansee, "Factors Influencing Selection of Resting Sites by Cattle on Shortgrass Steppe," Journal of Range Management, Vol. 38, No. 4, 1985, pp. 295-299. doi:10.2307/3899406

[3] D. Ganskopp, "Manipulating Cattle Distribution with Salt 
and Water in Large Arid-Land Pastures: A GPS/GIS Assessment," Applied Animal Behaviour Science, Vol. 73, No. 4, 2001, pp. 251-262.

doi:10.1016/S0168-1591(01)00148-4

[4] J. L. Holechek, "An Approach for Setting Stocking Rate," Rangeland, Vol. 10, No. 1, 1998, pp. 10-14.

[5] S. C. Martin and D. E. Ward, "Salt and Meal-Salt Help Distribute Cattle Use on Semi-Desert Range," Journal of Range Management, Vol. 26, No. 2, 1973, pp. 94-97. doi: $10.2307 / 3896459$

[6] E. J. Bowers, A. C. Hammond, C. C. Chase Jr. and T. A. Olson, "Effect of Breed on Indicators of Heat Tolerance and Grazing Activity in Lactating Angus and Brahman Cows in Florida," Journal of Animal Science, Vol. 73. No. S1, 1995, p.131.

[7] A. C. Hammond and T. A. Olson, "Rectal Temperature and Grazing Time in Selected Beef Cattle Breeds under Tropical Summer Conditions in Subtropical Florida," Journal of Tropical Agriculture (Trinidad), Vol. 71, No. 2, 1994, pp. 128-134.

[8] B. W. Mathews, L. E. Sollenberger, V. D. Nair and C. R. Staples, "Impact of Grazing Management on Soil Nitrogen, Phosphorus, Potassium, and Sulfur Distribution," Journal of Environmental Quality, Vol. 23, No. 5, 1994, pp. 1006-1013. doi:10.2134/jeq1994.00472425002300050022x

[9] B. W. Mathews, J. P. Tritschler, J. R. Carpenter and L. E. Sollenberger, "Soil Macronutrients Distribution in Rotationally Stocked Kikuyugrass Paddocks with Short and Long Grazing Periods," Communications in Soil Science and Plant Analysis, Vol. 30, No. 3-4, 1999, pp. 557-571. doi:10.1080/00103629909370226

[10] R. J. Haynes, "Competitive Aspects of the Grass-Legume Association," Advances in Agronomy, Vol. 33, 1981, pp. 227-261. doi:10.1016/S0065-2113(08)60168-6

[11] R. J. Haynes and P. H. Williams, "Nutrient Cycling and Soil Fertility in Grazed Pasture Ecosystem," Advances in Agronomy, Vol. 49, 1993, pp. 119-199. doi:10.1016/S0065-2113(08)60794-4

[12] G. C. Sigua and S. W. Coleman, "Sustainable Management of Nutrients in Forage-Based Pasture Soils: Effect Of Animal Congregation Sites," Journal of Soils and Sediments, Vol. 6, No. 4, 2007, pp. 249-253. doi:10.1065/jss2006.09.182

[13] J. O. Klemmendson and A. R. Tiedemann, "Effects of Nutrient Stress," In D. J. Bedunah and R. Sosebee Eds., Wildland Plants: Physiological Ecology And Developmental Morphology, Society for Range Management, Denver, Colorado, 1995 , p. 414-439

[14] A. J. Franzluebbers, J. A. Stuedeman and H. H. Schomberg, "Spatial Distribution of Soil Carbon and Nitrogen Pools under Grazed Tall Fescue," Soil Science Society of America Journal, Vol. 64, No. 2, 2000, pp. 635-639. doi:10.2136/sssaj2000.642635x

[15] S. L. White, R. E. Sheffield, S. P. Washburn, L. D. King and J. T. Green Jr., "Spatial and Time Distribution of
Dairy Cattle Excreta in an Intensive Pasture Systems," Journal of Environmental Quality, 30, 2001, pp. 2180-2187. doi:10.2134/jeq2001.2180

[16] P. R. Peterson and J. R. Gerrish, "Grazing Systems and Spatial Distribution of Nutrients in Pastures: Livestock Management Consideration," In R. E. Joost and C. A. Roberts Eds., Nutrient Cycling in Forage Systems, Potash and Phosphate Insti., Manhattan, 1996, pp. 203-212.

[17] K. W. Tate, E. R. Atwill, N. K. McDougald and M. R. George, "Spatial and Temporal Patterns of Cattle Feces Deposition on Rangeland," Journal of Range Management Applied Animal Behaviour Science, Vol. 56, No. 3, 2003, pp. 784-789.

[18] A. B, Botcher, T. K. Tremwel and K. L. Campbell, "Phosphorus Management in Flatwood (Spodosols) Soils," In K. R Reddy, et al. Eds., Phosphorus Biogeochemistry in Subtropical Ecosystems, Lewis Publishers, Boca Raton, FL. 1999, pp. 405-423.

[19] S. R. Carpenter, N. F. Caraco, D. L. Correll, R. W. Howarth, A. N. Sharpley and V.H. Smith, "Nonpoint Pollution of Surface Waters with Phosphorus and Nitrogen," Journal of Applied Ecology, Vol. 8, No. 3, 1998, pp. 559-568. doi:10.1890/1051-0761(1998)008[0559:NPOSWW]2.0.C $\mathrm{O} ; 2$

[20] D. L. Correll, "The Role of Phosphorus in the Eutrophication of Receiving Waters: A Review," Journal of Environmental Quality, Vol. 27, No. 2, 1998, pp. 261-266. doi:10.2134/jeq1998.00472425002700020004x

[21] G. C. Sigua, J. S. Steward and W. A. Tweedale, "Water Quality Monitoring and Biological Integrity Assessment in the Indian River Lagoon, Florida I. Status and Trends (1988-1994)," Journal of Environmental Management, Vol. 25, No. 2, 2000, pp. 199-209. doi: $10.1007 / \mathrm{s} 002679910016$

[22] G. C. Sigua and W. A. Tweedale, "Watershed Scale Assessment of Nitrogen and Phosphorus Loadings in the Indian River Lagoon Basin, FL," Journal of Environmental Management, Vol. 67, No. 4, 2003, pp. 361-370. doi:10.1016/S0301-4797(02)00220-7

[23] A. N. Sharpley, B. Foy and P. Withers, "Practical and Innovative Measures for the Control of Agricultural Phosphorus Losses to Water: An Overview," Journal of Environmental Quality, 29, 2000, pp. 1-9. doi: $10.2134 /$ jeq2000.00472425002900010001x

[24] J. T. Sims, "Phosphorus Soil Testing: Innovations For Water Quality Protection," Communications in Soil Science and Plant Analysis, Vol. 29, No. 11-14, 1998, pp. 1471-1489. doi:10.1080/00103629809370044

[25] H. H. Schomberg, J. A. Stuedemann, A. J. Franzlueber and S. R. Wilkinson, "Spatial Distribution of Extractable Phosphorus, Potassium, and Magnesium as Influenced by Fertilizer and Tall Fescue Endophyte Status," Agronomy Journal, Vol. 92, No. 5, 2000, pp. 981-986. doi:10.2134/agronj2000.925981x

[26] C. P. West, A. P. Mallarino, W. F. Wedin and D. B. Marx, "Spatial Variability of Soil Chemical Properties in Grazed 
Pastures," Soil Science Society of America Journal, Vol. 53, No. 3, 1989, pp.784-789. doi:10.2136/sssaj1989.03615995005300030026x

[27] J. T. Manley, G. E. Schuman, J. D. Reeder and R. H. Hart, "Rangeland Soil Carbon and Nitrogen Responses to Grazing,"Journal of Soil and Water Conservation, Vol. 53, No. 3, 1995, pp. 294-298.

[28] G. E. Schuman, J. D. Reeder, J. T. Manley, R. H. Hart and W. A. Manley, "Impact of Grazing Management on the Carbon and Nitrogen Balance of Mixed Grass Rangeland," Journal of Applied Ecology, Vol. 9, No. 1, 1999, pp. 65-71. doi:10.1890/1051-0761(1999)009[0065:IOGMOT]2.0.CO;2

[29] A. G. Hyde, L. Law, Jr., R. L Weatherspoon, M. D. Cheney and J. J. Eckenrode, "Soil Survey of Hernando County, FL," USDA-NRCS, Washington DC and University of Florida, Gainesville, FL., 1977, p. 152.

[30] C. G. Chambliss, "Florida Forage Handbook," University Florida Cooperative Ext. Service. SP, 1999, p. 253.

[31] A. Mehlich, "Determination of $\mathrm{P}, \mathrm{Ca}, \mathrm{Mg}, \mathrm{K}, \mathrm{Na}$, and $\mathrm{NH}_{4}$," North Carolina Soil Test Division, Raleigh NC. Mimeo, 1953, p. 16.

[32] SAS Institute, "SAS/STAT User's Guide. Release 6.03," SAS Institute, Cary, North Carolina, 2000, p. 494.

[33] D. B. Beegle, "Soil Fertility Management," In: F. Martz Ed., The Agronomy Guide, Publications Distirbution Center, College of Agricultural Sciences, The Pennsylvania State University, University Park, PA., 2000, pp. 19-42.

[34] J. T. Sims, R. O. Maguire, A. B. Leytem, K. L. Gartley and M. C. Pautler, "Evaluation of Mehlich-3 as an Agri -Environmental Soil Phosphorus Test for the Mid-Atlantic United States of America," Soil Science Society of America Journal, Vol. 66, No. 6, 2002, pp. 2016-2032. doi:10.2136/sssaj2002.2016

[35] D. Cluzeau, F. Binet, F. Vertes, J. C. Simon, J. M. Riviere and P. Trehen, "Effects of Intensive Cattle Trampling on Soil-Plant-Earthworms System in Two Grassland Types," Soil Biology \& Biochemistry,
Vol. 24, No. 12, 1992, pp. 1661-1992. doi:10.1016/0038-0717(92)90166-U

[36] S. W. Trimble, and A. C. Mendel, "The Cow as a Geomorphic Agent-A Critical Review," Geomorphology, Vol. 13, No. 1-4, 1995, pp. 233-253. doi:10.1016/0169-555X(95)00028-4

[37] R. O. Maguire, T. D. Jickells and M. J. Wilson, "Influence of Cultivation on the Distribution of Phosphorus in Three Soils from NE Scotland and Their Aggregate Fractions," Soil Use and Management, Vol. 14, No. S4, 1998, pp. 147-153. doi:10.1111/j.1475-2743.1998.tb00633.x

[38] L. Moughli, D. G. Westfall and A. Boukhial, "Use of Adsorption and Buffer Capacity in Soil Testing for Phosphorus," Communications in Soil Science and Plant Analysis, Vol. 24, No. 15-16, 1993, pp. 1959-1974. doi:10.1080/00103629309368930

[39] C. J. Penn, G. L. Mullins and L. W. Zelazny, "Mineralogy in Relation to Phosphorus Sorption and Dissolved Phosphorus Losses in Runoff," Soil Science Society of America Journal, Vol. 69, No. 5, 2005, pp. 1532-1540. doi:10.2136/sssaj2004.0224

[40] P. S. Hooda, A. R. Rendell, C. C. Edwards, P. J. Withers, M. N. Aitken and V. W. Truesdale, "Relating Soil Phosphorus Indices to Potential Releases to Water," Journal of Environmental Quality, Vol. 29, No. 4, 2000, pp. 1166-1171. doi:10.2134/jeq2000.00472425002900040018x

[41] R. O. Maguire, J. T. Sims and R. H. Foy, "Long Term Kinetics for Phosphorus Sorption-Desorption by High Phosphorus Soils from Ireland and the Delmarva Peninsula, USA," Soil Science, Vol. 116, No. 8, 2001, pp. 557-565. doi:10.1097/00010694-200108000-00007

[42] G. P. Heckrath, C. Brookes, P. R. Poulton and K. W. T. Goulding, "Phosphorus Leaching from Soils Containing Different Phosphorus Concentrations in the Broadbalk Experiment," Journal of Environmental Quality, Vol. 24, No. 5, 1995, pp. 904-910. doi:10.2134/jeq1995.00472425002400050018x 